\title{
Climate variability from the Florida Bay sedimentary record: possible teleconnections to ENSO, PNA and CNP
}

\author{
Thomas M. Cronin ${ }^{1, *}$, Gary S. Dwyer ${ }^{2}$, Sara B. Schwede ${ }^{1}$, Cheryl D. Vann ${ }^{1}$, \\ Harry Dowsett ${ }^{1}$
}

${ }^{1}$ United States Geological Survey, 926A National Center, Reston, Virginia 20192, USA

${ }^{2}$ Department of Geology, Duke University, Durham, North Carolina 27708, USA

\begin{abstract}
We analyzed decadal and interannual climate variability in South Florida since 1880 using geochemical and faunal paleosalinity indicators from isotopically dated sediment cores at Russell Bank in Florida Bay (FB). Using the relative abundance of 2 ostracode species and the $\mathrm{Mg} / \mathrm{Ca}$ ratios in Loxoconcha matagordensis shells to reconstruct paleosalinity, we found evidence for cyclic oscillations in the salinity of central FB. During this time salinity fluctuated from as low as $~ 18$ parts per thousand (ppt) to as high as $\sim 57 \mathrm{ppt}$. Time series analyses suggest, in addition to a $5.6 \mathrm{yr} \mathrm{Mg} / \mathrm{Ca}$ based salinity periodicity, there are 3 other modes of variability in paleosalinity indicators: $6-7,8-9$, and 13-14 yr periods which occur in all paleo-proxies. To search for factors that might cause salinity to vary in FB, we compared the Russell Bank paleosalinity record to South Florida winter rainfall, the Southern Oscillation Index (SOI), winter North Atlantic Oscillation (NAO), and the winter Pacific North American (PNA) index, and a surrogate for the PNA in the winter season, the Central North Pacific (CNP) index. SOI and PNA/CNP appear to be associated with South Florida winter precipitation. Time series analyses of SOI and winter rainfall for the period 1910-1999 suggest $\sim 5,6-7,8-9$ and 13-14 yr cycles. The 6-7 yr and 13-14 yr cycles correspond to those observed in the faunal and geochemical time series from Russell Bank. The main periods of the CNP index are 5-6 and 13-15 yr, which are similar to those observed in FB paleosalinity. Cross-spectral analyses show that winter rainfall and salinity are coherent at $5.6 \mathrm{yr}$ with a salinity lag of $\sim 1.6 \mathrm{mo}$. These results suggest that regional rainfall variability influences FB salinity over interannual and decadal timescales and that much of this variability may have its origin in climate variability in the Pacific Ocean/atmosphere system.
\end{abstract}

KEY WORDS: Paleoclimate $\cdot$ Florida Bay $\cdot$ Salinity $\cdot$ Shell geochemistry $\cdot$ ENSO $\cdot$ Pacific North American index

Resale or republication not permitted without written consent of the publisher

\section{INTRODUCTION}

A better understanding of the causes and impacts of decadal and interannual climate variability requires, in addition to observational and modeling studies, longer-term records of variables such as temperature and precipitation than are available from most instrumental records (Latif 1998). Paleoclimate records

*E-mail: tcronin@usgs.gov derived from ice cores (Thompson et al. 1984), tree rings (Stahle \& Cleaveland 1992, Stahle et al. 1998), corals (Dunbar et al. 1994), and rapidly deposited sedimentary sequences (Cronin et al. 2000) can provide excellent decadal-scale climate records, especially when they are located in areas sensitive to decadalscale processes. In addition to augmenting instrumental records and illustrating the impact of climate variability on ecosystems, paleoclimate records are also important for validating output from climate mod- 


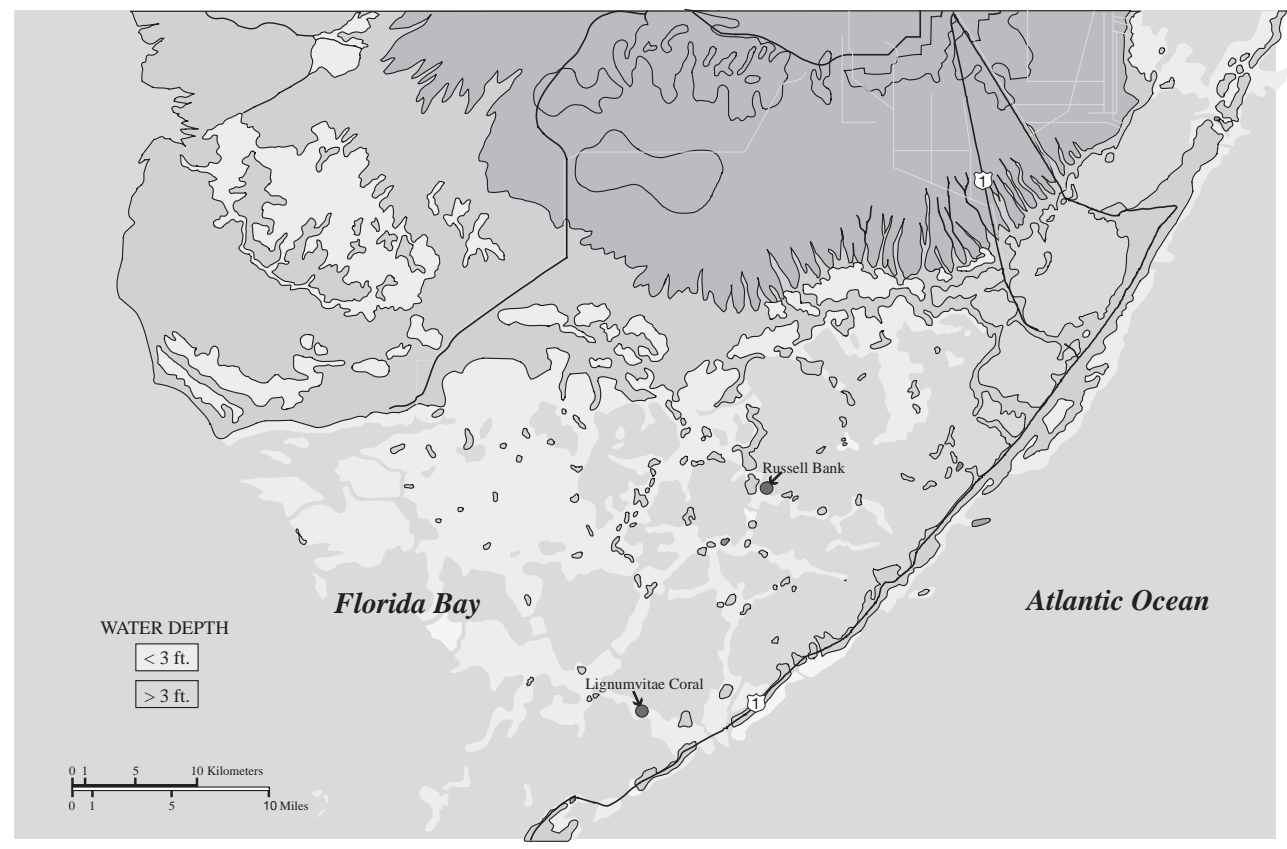

Fig. 1. Map of Florida Bay showing locations of the Russell Bank core site and Lignumvitae coral

els that simulate decadal patterns. For example, some model output and observational data suggest that causes of decadal variability occurring approximately every 20 yr reside in complex Pacific Oceanatmosphere interactions between tropical and midlatitude regions (Latif \& Barnett 1994, 1996, Meehl et al. 1998, Barnett et al. 1999). Climate variability in the Pacific region associated with a global mid- to upper tropospheric disturbance was called the Pacific North American (PNA) pattern by Wallace \& Gutzler (1981). More recently, the term Pacific Decadal Oscillation (PDO) has been applied to low-frequency oceanatmospheric variability originating in the Pacific region (Barnett et al. 1999). Similarly, surface oceanatmosphere interaction in the North Atlantic Ocean, called the North Atlantic Oscillation (NAO) (Rogers \& van Loon 1979, Rogers 1984), is a dominant mode of winter climate variability in the North Atlantic region, and also may influence spring and summer climate.

Several studies suggest that the southeastern United States is influenced by climate 'teleconnections' reflecting decadal and interannual ocean/atmospheric processes originating in the Pacific Ocean, and perhaps also the Atlantic Ocean, and thus may be an important source of long-term climate data. Leathers et al. (1991), Leathers \& Palecki (1992) and Henderson \& Vega (1996) examined the relationship between the PNA and climate in the southeast; Henderson \& Vega found that the PNA influenced regional climate, accounting for $28.2 \%$ of the variability in winter Florida rainfall. A positive PNA index brought enhanced atmospheric instability and a deep trough over the southeast, increased thunderstorms, and greater wintertime precipitation due to a predominately meridional atmospheric flow. Further, positive PNA values were associated with low winter atmospheric (Leathers \& Palecki 1992) and sea-surface (Slowey \& Crowley 1995) temperatures and high precipitation. Conversely, negative PNA values correlate with anomalies in the southeast region (Vega et al. 1998a). High-PNA conditions occurred in the 1960s following a shift from more zonal flow in the late 1950s.

The El Niño-Southern Oscillation (ENSO) mode of climate variability also has long been associated with anomalies in wintertime precipitation in the southeast (Douglas \& Engelhart 1981, Ropelewski \& Halpert 1986, 1987, Montroy 1997). Rainfall records from South Florida tend to confirm the existence of a $~ 5-6$ yr periodicity to interannual variability for the last century (Thomas 1974, Hanson \& Maul 1991, Henderson \& Vega 1996). In addition to these possible teleconnections, several studies have emphasized the interrelationship between PNA and ENSO climatological patterns in terms of southeastern US climate (Yarnal \& Diaz 1986, Vega et al. 1998b).

In the present study, we used geochemical and faunal proxies from the sedimentary record of Florida Bay (FB) to reconstruct its paleosalinity since 1880 in order to examine decadal and interannual climate variability (Fig. 1). FB, a large shallow embayment, experiences 
variations in salinity over seasonal, annual, and decadal timescales, largely due to changes in regional precipitation, freshwater runoff, and evaporation (Robblee et al. 1989, McIvor et al. 1994). We also compared the reconstructed FB salinity record to rainfall records and to trends in SOI and PNA/CNP indices to search for similarities with Pacific and Atlantic climate patterns. Finally, we discuss the FB salinity record in light of other paleoclimate records from the area to assess the major factors influencing southeastern US interannual and decadal climate variability.

\section{MATERIAL AND METHODS}

The material for this study was selected from several sediment cores taken on mudbanks in FB as part of a larger study to examine patterns and causes of ecosystem changes in the bay. We chose to focus on Core RB19-B $\left(25^{\circ} 03.83^{\prime} \mathrm{N}, 80^{\circ} 37.49^{\prime} \mathrm{W}, 0.5 \mathrm{~m}\right.$ water depth), a $1.4 \mathrm{~m}$ long core taken from Russell Bank located in the north-central part of the bay. The stratigraphy of FB mudbanks (Wanless \& Tagett 1989, Swart \& Kramer 1997) and the geochronology of RB-19B, dated at $1 \mathrm{~cm}$ intervals in the core by Robbins et al. (2000) and Holmes et al. (1998), indicate that this site is ideal for reconstructing FB salinity for 4 reasons. First, sedimentation was rapid, averaging $1.22 \mathrm{~cm} \mathrm{yr}^{-1}$ since 1880, and fairly continuous. Second, the stratigraphy is relatively undisturbed, minimizing the effects of sediment mixing by burrowing organisms. Third, the core contains excellent paleoenvironmental indicators, including mollusks (Brewster-Wingard et al. 1998), stable isotopes on mollusks (Halley \& Roulier 1998), calcareous microfossil assemblages (Cronin et al. 2001), and trace element geochemistry of ostracodes (Dwyer \& Cronin 2001). Finally, the core site location in central FB is known to experience wide seasonal and interannual oscillations in salinity, reaching values as high as 70 ppt and as low as 15 ppt (Robblee et al. 1989). It is important to emphasize that, although we focused on the core from Russell Bank, having the best chronology and temporal resolution, a number of cores from other central and northern regions of FB (i.e., Whipray, Park, Pass, Bob Allen Keys) also contain faunal and geochemical records of large-scale salinity oscillations over the past century (Brewster-Wingard et al. 1998, Cronin et al. 2001, Dwyer \& Cronin 2001).

Two proxies of FB salinity changes were used in this study: (1) faunal assemblage analyses of the abundance of salinity-sensitive ostracode species and (2) the trace element chemistry of the shells of the species Loxoconcha matagordensis. Ostracodes are small crustaceans that inhabit freshwater, brackish, marine, and hypersaline environments. They secrete a bivalved shell that is commonly preserved in sediments. Both ostracode assemblages (Cronin \& Raymo 1997) and shell chemistry (Dwyer et al. 1995, von Grafenstein et al. 1999) are increasingly being used for paleoclimate reconstructions in various aquatic ecosystems (see Holmes 1996). For the faunal analyses, sediment samples spaced $2 \mathrm{~cm}$ apart ( $2 \mathrm{yr}$ resolution) were processed at the US Geological Survey labs in Reston, Virginia. A standard 300 individuals of ostracodes were analyzed from the $>63 \mu \mathrm{m}$ size fraction of each sample. This sample size allows reliable estimates of the relative frequency of the key salinity-sensitive species in each sample. Species were identified, relative frequencies (percent of total assemblage) were computed for each species, and plotted against age as determined by ${ }^{210} \mathrm{~Pb}$ radiometric dating (Holmes et al. 1998).

For the trace elemental analyses, single adult shells of the species Loxoconcha matagordensis were cleaned by soaking for $24 \mathrm{~h}$ in Clorox, quadruple rinsed in deionized water, and dissolved in dilute nitric acid. Magnesium and calcium analyses of each shell were carried out using direct current plasma (DCP) emission spectrometry at Duke University. Concentrations of $\mathrm{Mg}$ and $\mathrm{Ca}$ were obtained and their ratios in mmol mol ${ }^{-1}$ were plotted against age. Three shells were analyzed for most intervals and used to calculate average $\mathrm{Mg} / \mathrm{Ca}$ ratios (see Dwyer \& Cronin [2001] for analytical details).

Time series analyses were performed on Loxoconcha matagordensis (LM), Malzella floridana (MF) (see Section 3.1), paleosalinity $\mathrm{Mg} / \mathrm{Ca}$, winter rainfall, SOI and CNP data. Power spectra were calculated using the Blackman-Tukey method (Jenkins \& Watts 1968). Paleosalinity indicators, winter rainfall, SOI and CNP were interpolated to an equi-distant time step of $1 \mathrm{yr}$, while LM, MF and paleosalinity $\mathrm{Mg} / \mathrm{Ca}$ had an equidistant time step of $1.6 \mathrm{yr}$. All paleosalinity indicators had scale lengths of 85 to 90 and were analyzed using 60 to 70 lags, resulting in a bandwidth of 0.190 to $0.222 \mathrm{yr}^{-1}$; LM, MF and paleosalinity Mg/Ca had scale lengths of 56 and were analyzed using 30 to 40 lags, resulting in a bandwidth of 0.208 to $0.277 \mathrm{yr}^{-1}$. All data were linearly detrended. Winter rainfall and paleosalinity $\mathrm{Mg} / \mathrm{Ca}$ were further examined using cross-spectral analysis. Data were interpolated to an equi-distant time step of $1.6 \mathrm{yr}$, linearly detrended, and analyzed using 25 lags, resulting in a bandwidth of $0.333 \mathrm{yr}^{-1}$.

South Florida rainfall was obtained from National Atmospheric and Oceanic Administration records back to 1895, archived at the National Climate Data Center Website CLIMVIS: http://www.ncdc.noaa.gov/onlineprod/drought/xmgr.html\#gr. We used mean monthly data from NOAA Florida sector 5 summed accordingly to produce annual winter rainfall plots. The SOI and PNA indices were obtained from the following UCAR and 


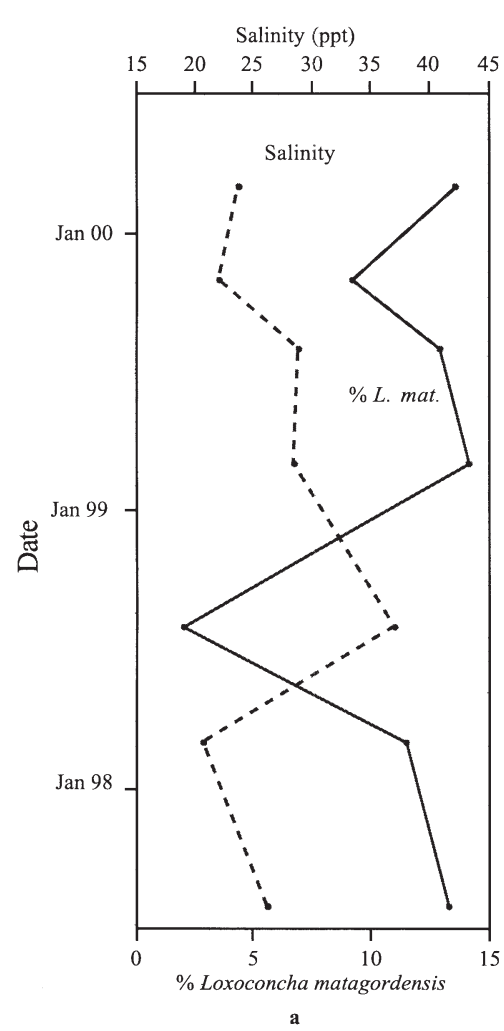

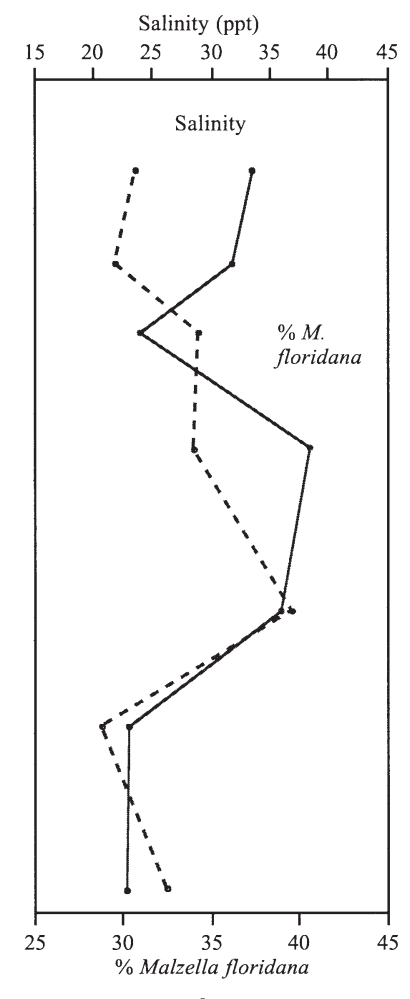

b

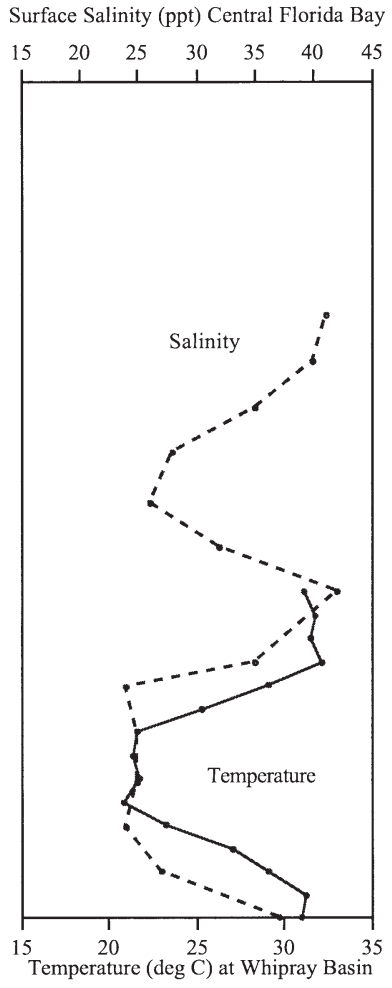

c

Fig. 2. (a,b) Relationship between relative abundance of the ostracodes species (Loxoconcha matagordensis, LM, and Malzella floridana, MF) from modern vegetation samples and measured salinity; LM decreases with higher salinity and MF increases with higher salinity. (c) Surface salinity data from central Florida Bay from R. Halley (http://sofia.usgs.gov/exchange/halley/ halleysalt.html) and temperature at Whipray Basin from an Everglades National Park water monitoring station

University of Washington Websites: http://www.cgd. ucar.edu/cas/climind/soi.html and http://tao.atmos. washington.edu/data_sets/pna/.

\section{PALEOSALINITY PROXIES}

\subsection{Salinity-sensitive species}

In coastal bays and estuaries, salinity is a predominant controlling factor on the distribution and abundance of organisms. In FB, 2 species, Loxoconcha matagordensis (LM) and Malzella floridana (MF), having known salinity tolerances from several studies (King \& Kornicker 1970, Keyser 1977, Garbett \& Maddocks 1978), were used to establish relative trends in salinity. We augmented the prior information on these species' ecology by studying their seasonal abundance between July 1997 and February 2000. Fig. 2 shows the relationship between the relative frequencies of LM and MF collected from Russell Bank and the measured salinity and water temperature during this period. The data show positive and negative relationships between salinity and MF and LM, respectively.
During summer months, when salinity reaches annual maxima, MF reaches $\sim 40 \%$ of the total assemblage, whereas LM increases to $10-15 \%$ when salinity decreases. Moreover, during the past 2 decades, when central FB has experienced periods of hypersalinity up to $70 \mathrm{ppt}$, MF comprised 50 to $60 \%$ of the assemblage (Cronin et al. 2001), also indicating its preference for high salinity. King \& Kornicker (1970) also showed that MF in Texas bays comprised 90 to $100 \%$ of assemblages during summer and early fall months, when salinity in the Upper Laguna Madre rose to $50 \mathrm{ppt}$, but was virtually absent from Copano Bay, where salinity rarely exceeded 15 ppt.

It is also important to emphasize the limitations of faunal assemblage analyses. For example, other environmental and ecological factors such as substrate, dissolved oxygen, food and nutrients can influence the abundance of aquatic species. LM, for example, is an epiphytal species that lives on the leaves of seagrasses such as Thalassia testudinum, and the stratigraphic and monitoring records suggest there have been large fluctuations in seagrass abundance in several areas of FB over the past century. Anoxia can also prevent populations from colonizing an area; however anoxia does 
not seem to be a severe problem in FB (W. Lyons pers. comm.). Despite these other factors, abundant ecological data indicate that MF prefers higher salinity, including hypersalinity for at least some time during the year. LM prefers lower, more fluctuating salinity, and requires a seagrass habitat.

\subsection{Salinity control of trace element shell chemistry}

The second method to reconstruct salinity uses the calcitic shells of ostracodes. The ostracode shell is composed mostly of the mineral calcite $\left(\mathrm{CaCO}_{3}\right)$, which coprecipitates minor amounts of foreign metals such as magnesium and strontium into the crystal lattice in place of calcium. Mg uptake into the ostracode shell can be described by the following equation:

$$
(\mathrm{Mg} / \mathrm{Ca})_{\text {ostracode calcite }}=\left(K_{\mathrm{D}-\mathrm{Mg}}\right)\left(\mathrm{Mg} / \mathrm{Ca}_{\text {water }}\right)
$$

where $\mathrm{Mg} / \mathrm{Ca}$ represents the atomic ratio of $\mathrm{Mg}$ to $\mathrm{Ca}$, and $K_{\mathrm{D}-\mathrm{Mg}}$ is the $\mathrm{Mg}$ partition coefficient for $\mathrm{Mg}$ in calcite. If $K_{\mathrm{D}-\mathrm{Mg}}$ is constant or can be constrained, then the $\mathrm{Mg} / \mathrm{Ca}$ ratio in ostracode calcite can be used to determine the $\mathrm{Mg} / \mathrm{Ca}$ ratio of the water in which the shell grew (see Wansard 1996). Because Mg/Ca ratios in FB water appear to vary with salinity probably as a result of mixing between freshwater runoff and discharge from the adjacent Everglades, and seawater (Dwyer \& Cronin 2001, Fig. 3), (Mg/Ca) $)_{\text {water, }}$ as calculated from

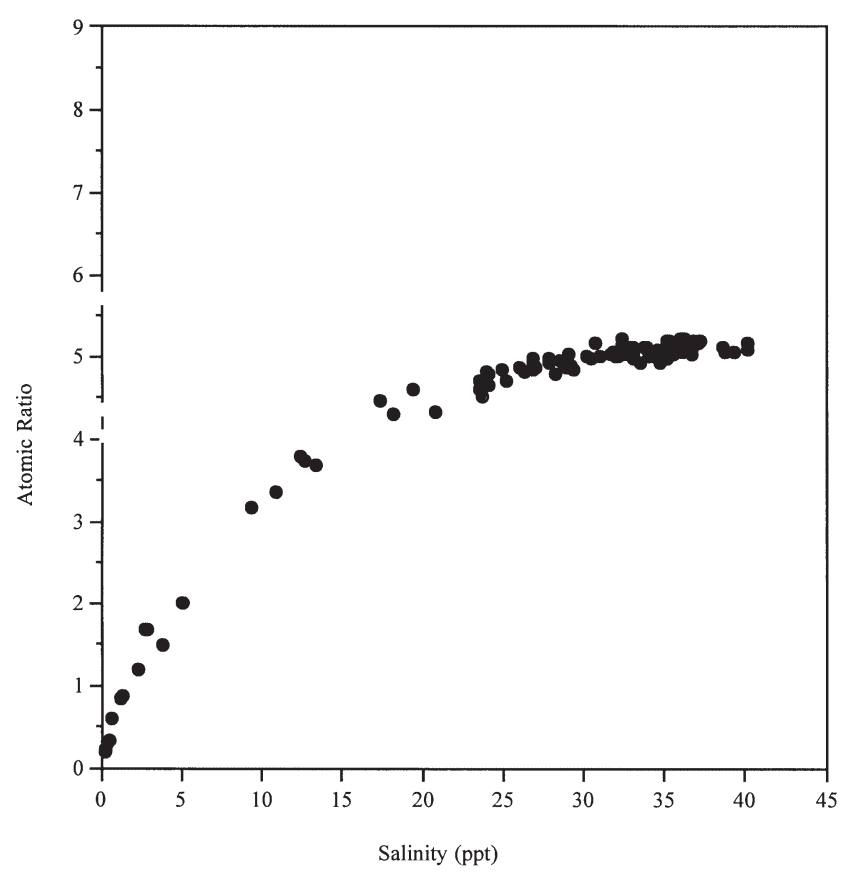

Fig. 3. $\mathrm{Mg} / \mathrm{Ca}$ ratio from ostracode shells plotted against salinity of water collected at sites from Florida Bay
$(\mathrm{Mg} / \mathrm{Ca})_{\text {ostracode calciter }}$ can thus be used to estimate FB salinity. Because most LM secrete their shells during spring and summer seasons (Tressler \& Smith 1948, King \& Kornicker 1970, Cronin \& T. Kamiya unpubl. data), the trace element signal at Russell Bank is primarily a spring/summer salinity signal.

In addition to $(\mathrm{Mg} / \mathrm{Ca})_{\text {water, }}$ factors such as temperature (Chave 1954, Cadot \& Kaesler 1977, Chivas et al. 1983, Burton \& Walter 1991, Dwyer et al. 1995) can potentially control the uptake of foreign ions into calcite. Such may be the case at times when salinity exceeds $\sim 40 \mathrm{ppt}$, because above this level $(\mathrm{Mg} / \mathrm{Ca})_{\text {water }}$ may not change substantially (Fig. 3). Although the relative contribution of temperature and salinity varies across different taxa and environments (Wansard 1996, De Deckker et al. 1999), water temperature and salinity in FB are positively correlated (e.g., Coleman 1988), and it is likely that periods of highest $\mathrm{Mg} / \mathrm{Ca}$ ratios signify the periods of highest temperature and salinity.

\section{SOUTH FLORIDA CLIMATOLOGY AND FLORIDA BAY OCEANOGRAPHY}

The climate in South Florida is subtropical, with annual minimum December/January and average maximum July/August temperatures of about 10 and $31^{\circ} \mathrm{C}$, respectively (Duever et al. 1994). Temperatures fall below $10^{\circ} \mathrm{C}$ only during occasional winter cold fronts. There is a characteristic wet summer season (60\% of precipitation falls between June and September) and a dry winter season (about $25 \%$ total annual rainfall arrives between November and April). However, winter rainfall shows much greater interannual variability (70 to $80 \%$ relative to standard deviation) compared to summer rainfall ( 20 to $25 \%)$, which is why wintertime forcing of rainfall variability discussed below is so important to regional climatology and FB salinity. There is a 5-6 yr periodicity in annual rainfall (especially in winter rainfall) (Hanson \& Maul 1991), and occasional tropical cyclones have landfall in south Florida, mostly in August through October. Coleman (1988) discussed the sources and patterns of Florida precipitation in detail.

FB is a shallow (1 to $3 \mathrm{~m}$ water depth), semi-enclosed embayment bordered by peninsular Florida on the north, the Florida Keys on the southeast, and the Gulf of Mexico on the southwest. It is subdivided into a complex of shallow, semi-isolated basins separated by mudbanks and islands that have partially restricted flow between them (Wanless et al. 1995, Swart \& Kramer 1997). Water temperatures range from usually $20^{\circ} \mathrm{C}$ in winter (occasionally dropping to $15^{\circ} \mathrm{C}$ ) to $>30^{\circ} \mathrm{C}$ during summer months. Salinity also varies 
greatly regionally, seasonally, and interannually. In central FB near the Russell Bank core site, for example, surface salinity ranged from 22 to 40 ppt from late 1997 to 1999 (http://sofia.usgs.gov/exchange/halley/ halleysalt.html or http://flaecohist.er.usgs.gov/database/ FB/Field/FBSalTempField1_1.IDC). Salinity in western FB is relatively stable, buffered by exchange with Gulf of Mexico marine waters. Salinity along the northern border of the bay is variable and strongly influenced by freshwater influx from the adjacent Everglades. The possible influence of decreased freshwater inflow due to post-1940 agriculture and urban land use has been widely disputed in terms of its influence on FB salinity over the past century (e.g., Smith et al. 1989). Swart et al. (1996, 1999) and Halley \& Roulier (1998) argue, however, that there has been no long-term increase in salinity in FB due to post-1940 water management, but both studies suggest that the building of the railroad between 1905 and 1912 from Miami to Key West altered circulation in the bay. It appears that the impact of canal-building, in terms of salinity, has been mainly felt along the northern margin of the bay and has had minor effects in the study area.

\section{RESULTS}

\subsection{Time series in salinity indicators}

Fig. 4 shows time series in the 2 species and salinity estimated from $\mathrm{Mg} / \mathrm{Ca}$ ratios in shells. Several important patterns emerge. First, both species have large changes in their relative frequencies from $<10 \%$ to $\sim 35 \%$ for LM and $\sim 10 \%$ to as high as $\sim 55 \%$ for MF. There is also a prominent shift in the abundance of LM beginning in the 1930s that has been interpreted as a change in the benthic environment from one with minimal seagrass cover to one with extensive subaquatic vegetation (Brewster-Wingard \& Ishman 1999, Cronin et al. 2001). Since the mid-century, there have been wide swings in the abundance of both species which, especially in the case of LM, exceeded the level of variability prior to $\sim 1940$.

The $\mathrm{Mg} / \mathrm{Ca}$ based salinity curve also reveals wide and sometimes rapid oscillations in which this part of FB experienced polyhaline conditions (18 to $30 \mathrm{ppt}$ ) alternating with hypersalinity conditions (salinity at times exceeding $40 \mathrm{ppt}$ ). There is also concordance
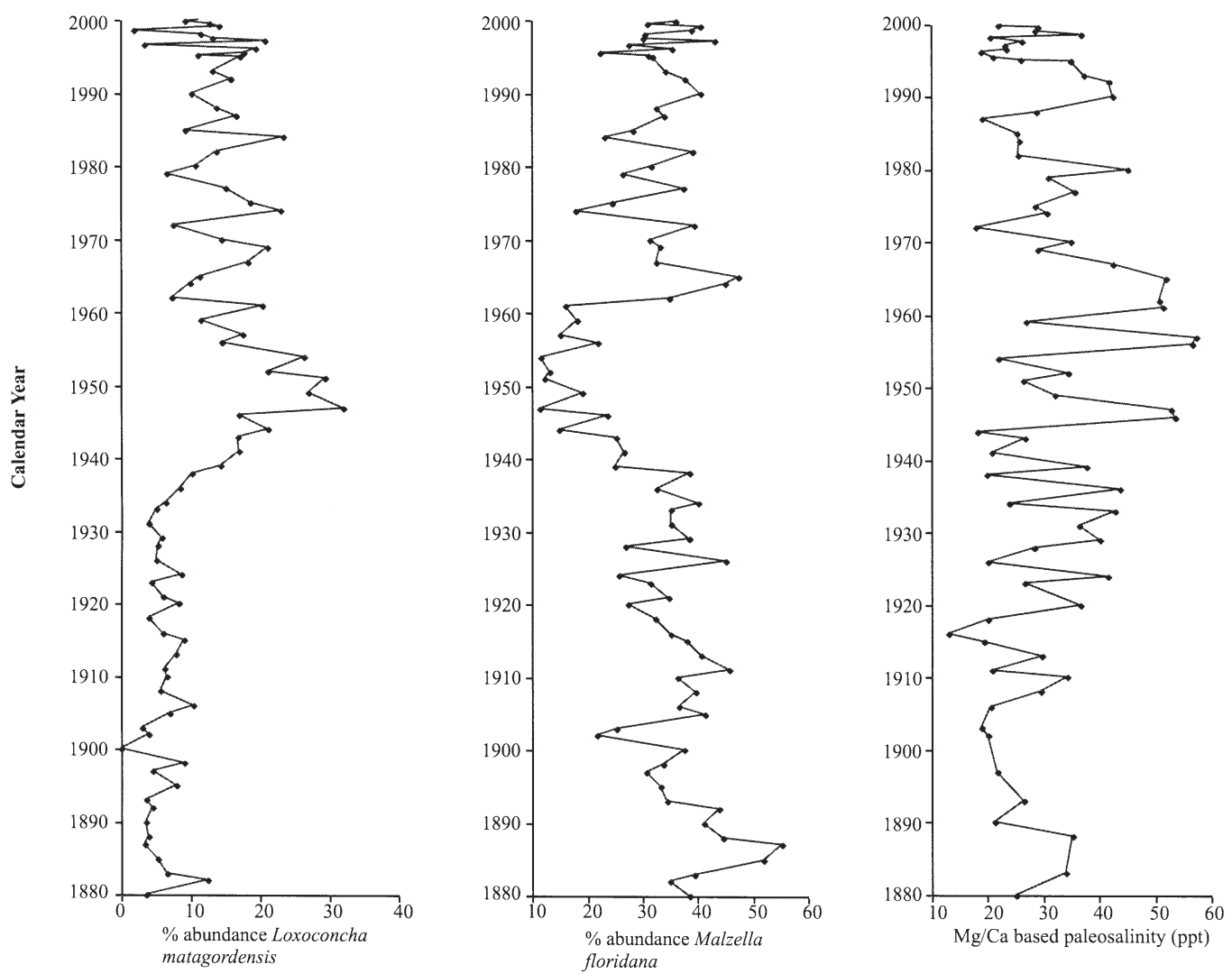

Fig. 4. Trends in percent abundance of the ostracode species Loxoconcha matagordensis and Malzella floridana and the paleosalinity curve calculated from Mg/Ca ratios in sediment core from Russell Bank core for the period 1880-1995. Faunal abundances and salinity measurements for the period 1995-2000 were obtained from living collections taken at Russell Bank 
between the $\mathrm{Mg} / \mathrm{Ca}$ and the MF record, which is most obvious during periods of high salinity in the 1880s, 1905-1915, 1930s, 1960s, late 1970s, early 1980s and the early 1990s. A brief period of high salinity around 1950 is not recorded in the MF record, perhaps due to its brief nature or to other factors influencing the benthic ecosystem at that time.

\subsection{Time series in rainfall and climate indices}

Fig. 5 presents the record of south Florida winter rainfall 1885-1999, the SOI from 1882 to 1998, the winter Pacific North American index from 1950 to 1998, and the CNP index back to 1899. The inverse relationship between rain and SOI (high rainfall = low SOI index) reflects the well-known teleconnection between ENSO patterns in the Pacific Ocean and climate in the southeastern United States (Ropelewski \& Halpert 1987). The strong 1982/83 and 1997/98 El Niño events are evident in the Florida rainfall record.

Less apparent is the shift during the late 1950s from low to high PNA values (see Leathers \& Palecki 1992).
Although the PNA index is available only as far back as about 1947, Slowey \& Crowley (1995) used Gulf of Mexico sea-surface temperature and coral growth patterns as surrogates for the PNA and showed that the 1950s climatological shift represented a significant event relative to others over the past century. The CNP curve reflects the strong association of this index with SOI variability, a drop in CNP values during the early 1920 s, and the prominent increase in values between 1940 and 1950 (Cayan \& Peterson 1989).

\subsection{Spectral analyses of salinity, rainfall and climate indices}

Power spectra for the 3 salinity indicators, rainfall, SOI, and CNP indices for the periods of 1910-1998, 1910-1999 and 1910-1994, respectively, are given in Fig. 6. The plot reveals several important periodicities that suggest associations between FB salinity and interannual and decadal climate patterns. First, there is a prominent $\sim 5.6 \mathrm{yr}$ period for salinity, rainfall, SOI, and CNP and an equally strong $\sim 6.0-7.0$ yr period for
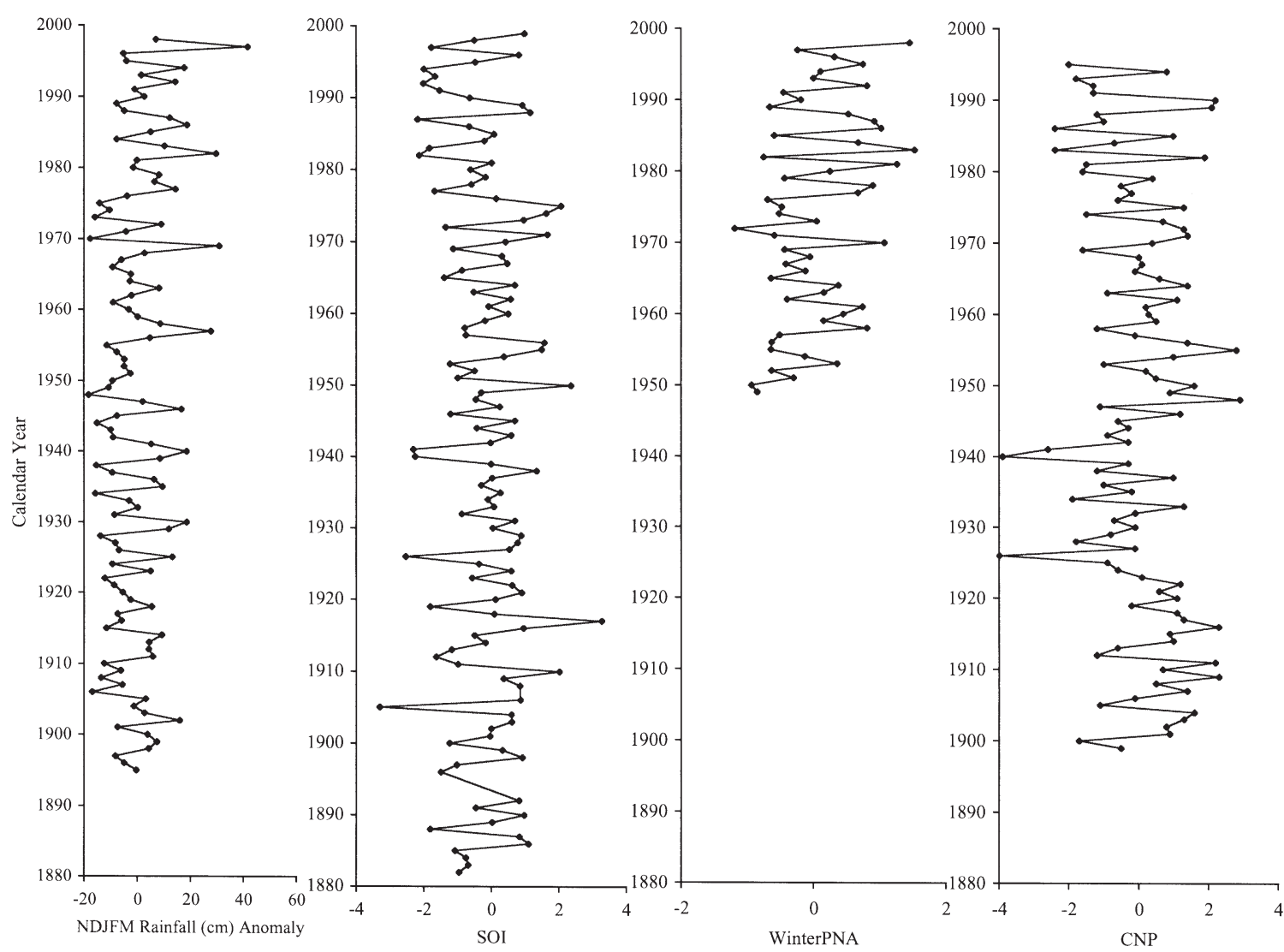

Fig. 5. Records of south Florida winter rainfall for 1885-1999, the Southern Oscillation Index (SOI) for 1882-1998, the winter Pacific North American (PNA) index for 1950-1998, and the Central North Pacific (CNP) index back to 1899 


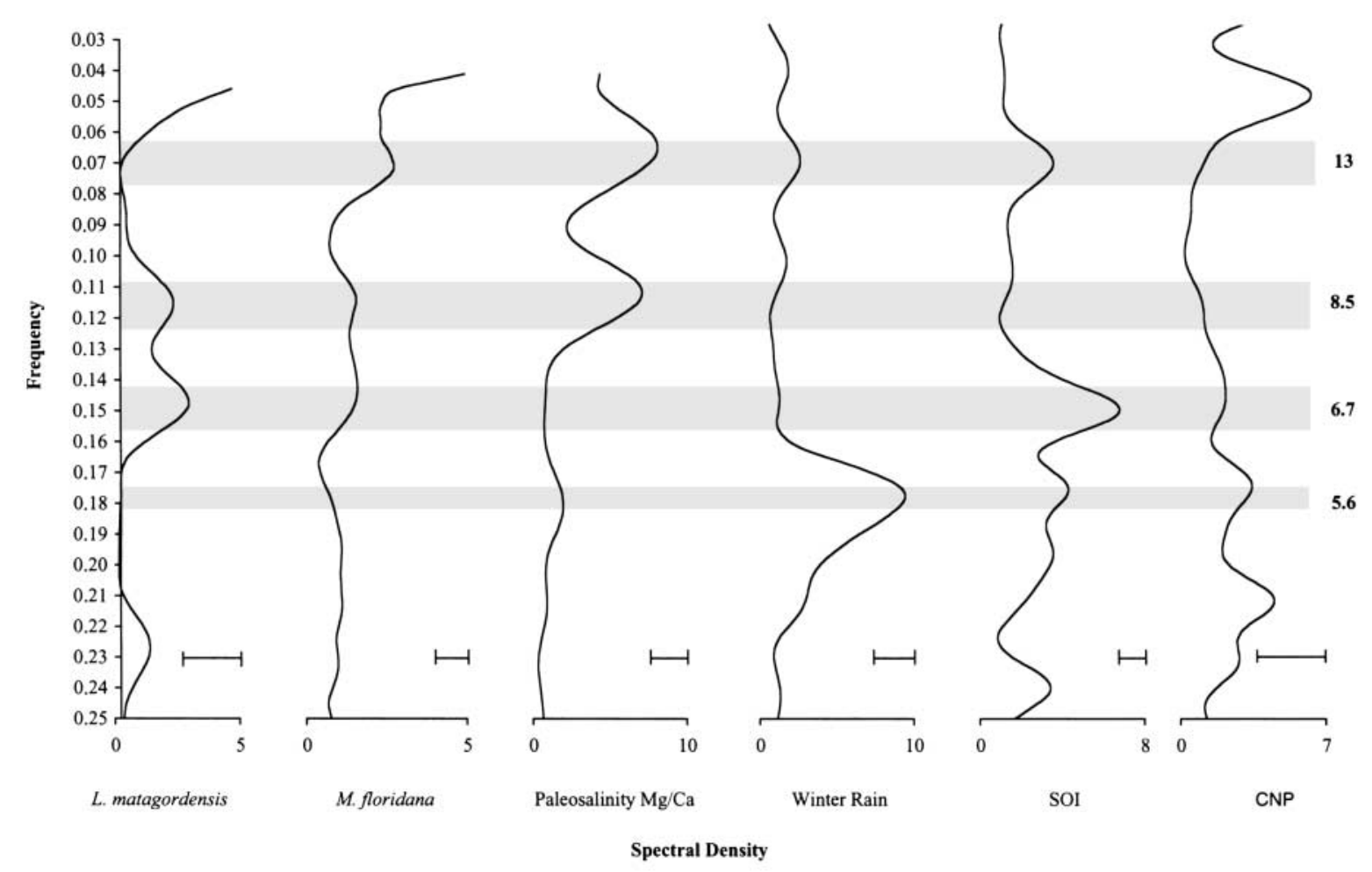

Fig. 6. Power spectra for the period 1910-1999 for the abundance of Loxoconcha matagordensis and Malzella floridana, Mg/Ca based salinity, winter rainfall, SOI and CNP. Frequency is plotted linearly on the vertical axis. Periods of specific interest discussed in the text are shown as horizontal bands. Bars representing $95 \%$ confidence level are shown at bottom right of each spectra. A concentration of power at the 5.6 or $6.7 \mathrm{yr}$ El Niño bands is found for most variables during the last century

LM, MF, SOI and CNP. High rainfall occurs every 5-6 yr during period of strong El Niño events (low SOI), and these events are accompanied by relatively low salinity in this part of FB.

Power spectra also show a concentration of variance at about 13-14 yr. This pattern is most obvious in the $\mathrm{SOI}$ and $\mathrm{Mg} / \mathrm{Ca}$ paleosalinity records. Spectral peaks of 13-14 yr also characterize the $\mathrm{MF}$, rainfall and CNP records.

\subsection{Cross spectral analysis of winter rainfall and Mg/Ca based salinity}

In order to examine the phase relationships between patterns of winter rainfall and FB salinity, we performed cross spectral analyses for the period 1910-1998 (Fig. 7A,B). The results reveal a coherent relationship between rainfall and salinity at a period of $5.6 \mathrm{yr}$, with salinity lagging rain by $1.6 \mathrm{mo}$, which is consistent with patterns of surface water flow in the adjacent Everglades. Coherent rainfall/salinity relationships are also evident at 8-9 and 13-14 yr periods (Fig. 7A). For the 13-14 yr period, salinity lags rainfall by about $8 \mathrm{yr}$ (not shown). It is not clear what processes might be responsible for an $8 \mathrm{yr}$ lag; it may be related to surface and groundwater flow of freshwater in the Everglades and underlying carbonate bedrock.

\section{COMPARISON WITH OTHER PALEOCLIMATE RECORDS}

Whereas the Russell Bank record is sensitive to salinity variability in the central $\mathrm{FB}$, a detailed oxygen isotopic $\left(\delta^{18} \mathrm{O}\right)$ salinity/rainfall record from a Solenastrea bournoni coral from Lignumvitae Basin in the southern portion of FB (see Fig. 1) (Swart et al. 1996, 1999) provides a complementary data set with which to examine possible climate/salinity linkages. Fig. 8 illustrates the $\mathrm{Mg} / \mathrm{Ca}$ based paleosalinity, the winter rainfall, and the coral isotopic records. Recognizing that the age dating of the Russell sediment core record have an error of $\pm \sim 2$ yr, compared to the sub-annual resolution of coral, the similarity between the 2 salinity records and their relationship to rainfall is striking. Extremely wet periods with low salinity are evident between 1890 and 1905, between 1915 and 1920, intermittently between 1920 and 1945, in the late 1960s, in the early 1970s, in the mid 1980s and in the late 1990s. The period near the turn of the century is especially noteworthy as the 
Mg/Ca record shows that between 1890 and 1920 there were no strong periods of hypersalinity. During this same time, winter rainfall was persistently high, only once falling to $10 \mathrm{~cm}$. Although the pre-1910 oxygen isotope record may have been influenced by circulation changes due to railroad construction between the Florida Keys (Swart et al. 1996), part of the strong negative isotopic values may reflect lower salinity due to enhanced rainfall.

Periods of low rainfall and high salinity alternated with high rainfall and low salinity. For example, most of the 1960s were characterized by extremely low rainfall and high salinity in both central and southern FB. Swart et al. (1999) and Dwyer \& Cronin (2001) point out that the $\delta^{18} \mathrm{O}$ and $\mathrm{Mg} / \mathrm{Ca}$ records for this period indicate the highest FB salinity for the past 170 and $120 \mathrm{yr}$, respectively. Since the 1960 s salinity maximum, there appears to be a stepwise decrease in salinity and increase in rainfall. Less prominent salinity maxima are evident in the 1970 s and late 1980 s in both $\mathrm{Mg} / \mathrm{Ca}$ and coral isotopic records. There are 2 salinity peaks in central FB during the late 1940s and early 1950s that
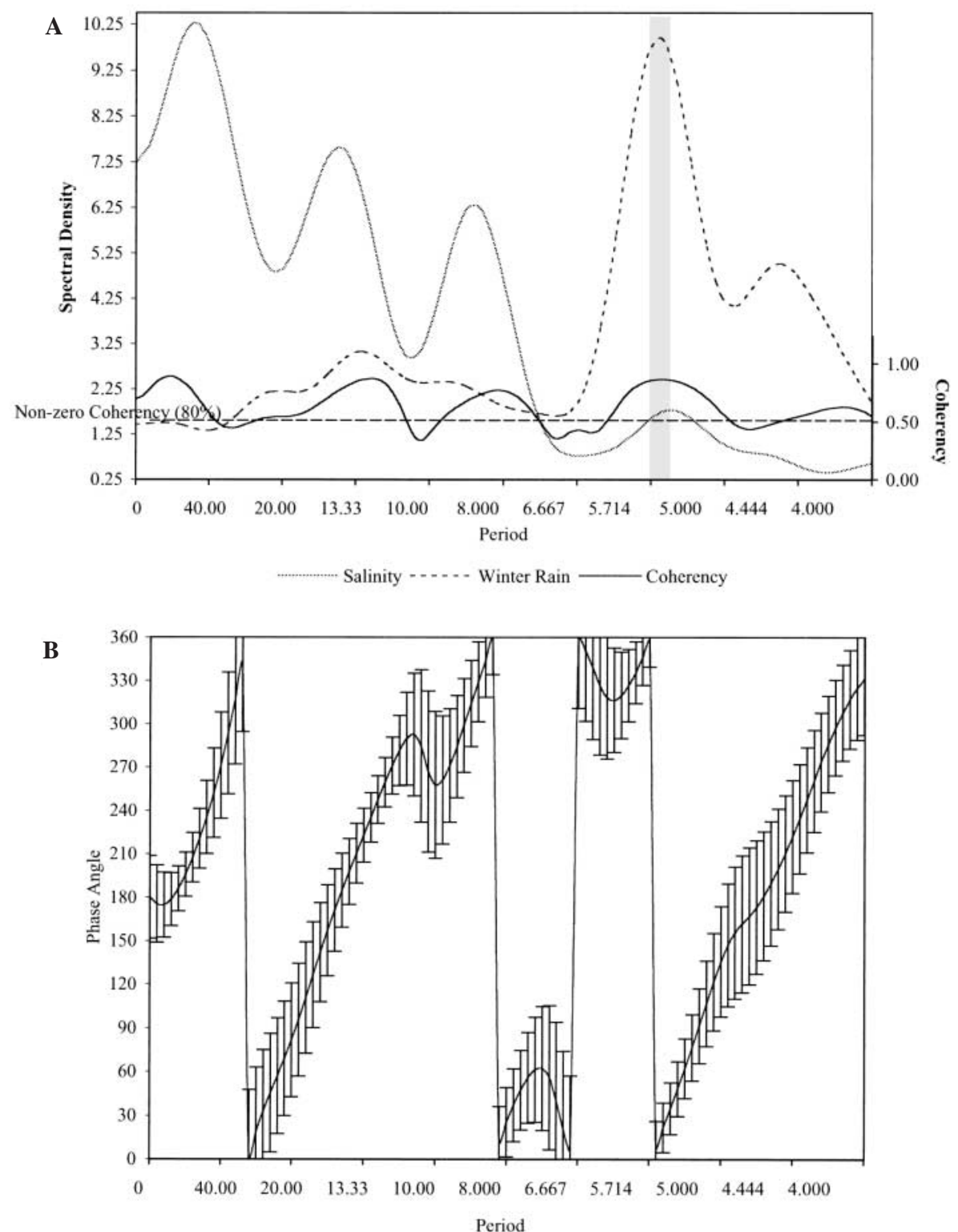

Fig. 7. Cross spectral analysis of winter rainfall and Mg/Ca based salinity for the period 1910-1999. (A) Horizontal dashed line indicates non-zero coherency at the $80 \%$ confidence level. Concentration of power at a period of 5.6 yr is shown by a vertical bar. (B) Coherent phase relationship between winter rainfall and $\mathrm{Mg} / \mathrm{Ca}$ based salinity. At a period of $5.6 \mathrm{yr} \mathrm{Mg} / \mathrm{Ca}$ based salinity lags winter rainfall by $8.9^{\circ}$ or $1.6 \mathrm{mo}$ 


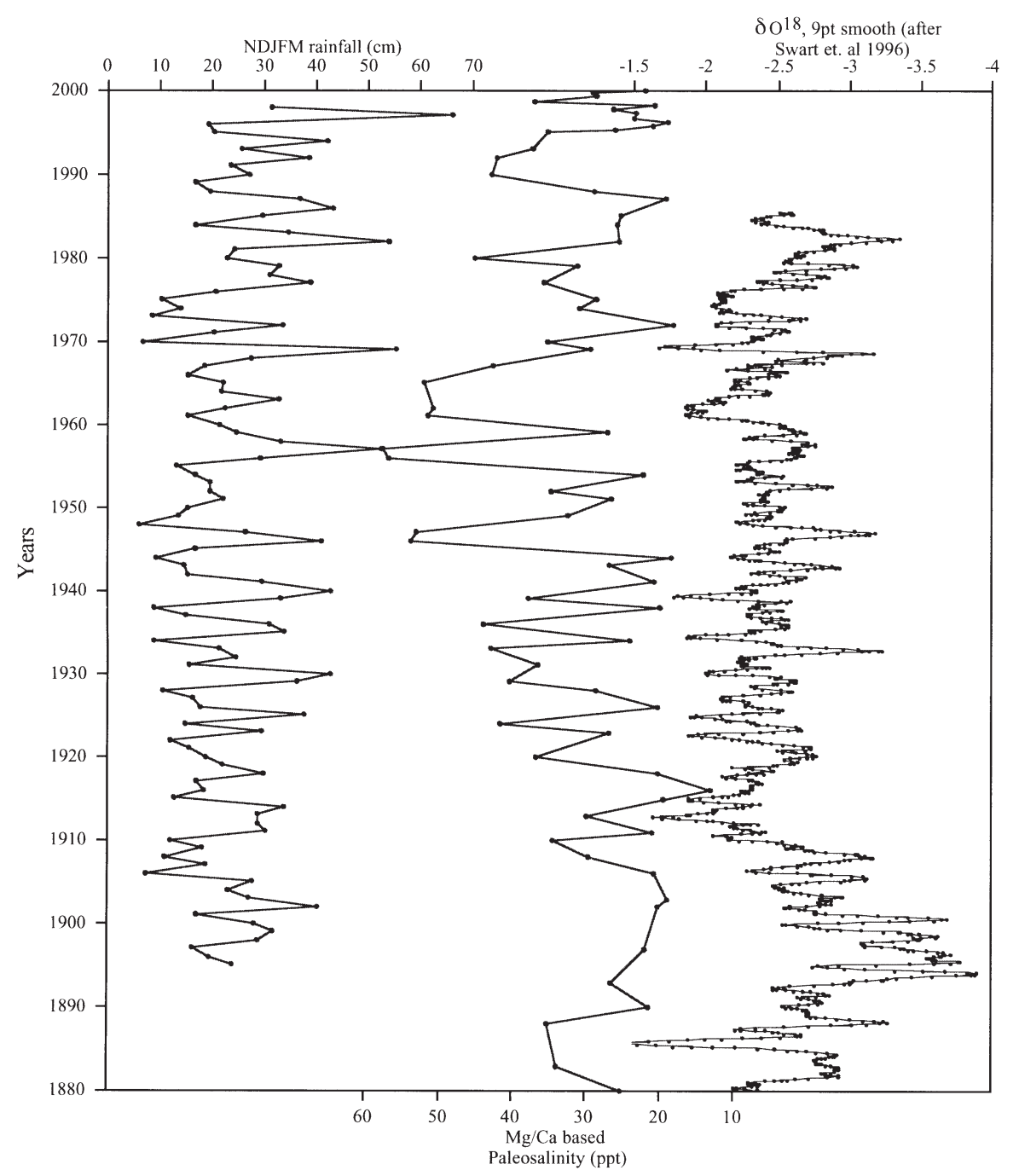

Fig. 8. Relationship between $\mathrm{Mg} / \mathrm{Ca}$ based paleosalinity in the Russel Bank core, winter rainfall, and $\delta \mathrm{O}^{18}$ from the Lignumvitae coral record (from Swart et al. 1996)

do not appear in the coral record, perhaps because the southern part of the bay was not affected by these events.

The periodicity of FB salinity oscillations discussed above is also largely supported by other paleo-records from the region. Swart et al. (1999) examined the coral isotopic record for spectral peaks and found dominant signals at 4-7, 28 and 12-14 yr accounting for 22, 13 and $9 \%$ of the variance, respectively. The $4-7$ and 12-14 yr peaks are particularly noteworthy in their correspondence to the faunal and $\mathrm{Mg} / \mathrm{Ca}$ peaks discussed above. Further support for an ENSO-related signal in FB is found in the study by Smith et al. (1989) of the same Lignumvitae coral studied by Swart et al. (1999). Citing the relationship between the fluorescence of coral skeletal and freshwater influx, Smith et al. discovered that a 4-6 yr spectral peak in coral fluorescence for the period prior to 1932 characterized the coral record. Between the 1930s and the 1980s, Smith et al. found that fluorescence and salinity showed an irregular pattern of variability characterized by higher amplitude and lower frequency salinity variability than that which had occurred in the 19th and early 20th centuries. They inferred that the major change in coral fluorescence was the result of reduction in freshwater flow via Shark River Slough.

In summary, coral isotopic and fluorescence records from southern FB provide independent records of oscillating salinity at periods similar to those revealed by the faunal and $\mathrm{Mg} / \mathrm{Ca}$ records at Russell Bank.

\section{DISCUSSION AND CONCLUSIONS}

Deciphering which climate processes have influenced regional climate is difficult because of 'overlap- 
ping' forcing functions; interannual and decadal climate processes are quasi-periodic due to frequency and/or amplitude modulation. This is particularly relevant for the present study of climate in the southeastern US because, for example, Yarnal \& Diaz (1986) showed that during 'warm' ENSO events PNA values are more positive. Vega et al. (1998b) also proposed that major changes in atmospheric circulation over the southeastern US during extreme phases of ENSO are similar to regional precipitation responses produced by PNA teleconnections. Moreover, it is possible that processes stemming from the Atlantic regions (i.e., North Atlantic Oscillation) may modulate rainfall variability in south Florida related to ENSO and PNA/CNP.

Despite these complexities, the results presented here and in prior studies of paleosalinity using corals provide evidence for predominant modes of variability in salinity indicators during the last century occurring in 5-6, 6-7, 8-9, and $13-14$ yr cycles. The 5-6 and 6-7 yr salinity patterns are reminiscent of ENSOrelated anomalies in observational data. For example, these results are consistent with those of Thomas (1974), who analyzed 19th and 20th century climatological and hydrological records of south Florida and discovered a 5 yr cycle in rainfall since 1914 in the Florida Keys and along the eastern coastal region. At that time the ultimate causes of the 5 yr cycle were not known. Later, Ropelewski \& Halpert (1986) demonstrated that ENSO-related 'teleconnections' could be recognized in the southeastern US. They showed, for example, that the southeastern US was anomalously wet during October through March in 18 of last 22 ENSO warm episodes, based on records extending back to the early part of the 20th century. Hanson \& Maul (1991) also studied Florida precipitation records for the period 1895-1989 and discovered a strong 5-6 yr cyclicity in rainfall related to ENSO activity. Above-average rainfall characterized the entire state of Florida during winter and spring of an El Niño year, and the largest rainfall anomalies were in the southern parts of Florida.

Sittel $(1994 a, b)$ contrasted temperature and precipitation extremes between El Niño and La Niña conditions and those during 'neutral' years for the past $40 \mathrm{yr}$. During El Niño years, Sittel found that in South Florida rainfall anomalies for the winter season were extremely high; average monthly precipitation anomalies reached 4 to $6 \mathrm{~cm}$ above those of neutral years. In contrast, during La Niña years, winter conditions were relatively dry. Montroy (1997) also studied the relationship between Pacific Ocean tropical sea-surface temperatures (SST), a useful index of the strength of El Niño events, and eastern North American monthly rainfall patterns. He found that rainfall in the southeastern US was positively correlated with central and eastern Pacific Ocean SSTs for the months of November to March.

The hypothesis of ENSO-driven salinity variability is also consistent with current conditions in FB. A severe drought occurred in South Florida in 2000/2001, which coincides with La Niña conditions in the Pacific Ocean. Salinity levels in parts of FB were approaching $\sim 45 \mathrm{ppt}$ by spring 2001. This hypersalinity is in strong contrast to the relatively low salinity during the wet 1997/98 El Niño event.

The existence of 13-14 yr cycles in both the $\mathrm{Mg} / \mathrm{Ca}$ salinity indicators and stable isotopic records of corals (Swart et al. 1999) provides evidence for decadal-scale variability in FB salinity. It appears that the observed 20th century 13-14 yr period (and perhaps the 8-9 yr cycle) in FB salinity may be related to climate processes captured by the CNP index. Cayan \& Peterson (1989) applied the CNP index to the study of streamflow in western North America and suggested that it was also related to decadal climate variability (wintertime precipitation) in the southeastern US over the past century. Leathers et al. (1991) also showed a connection between PNA and southeastern US climate for the post-1947 period. Additional work, however, is required to determine how processes governing the flow of surface and groundwater into FB, the effects of evaporation and temperature on salinity, and the influence of Gulf of Mexico water affect salinity in the bay.

Acknowledgements. We are grateful to Charles Holmes and Lynn Wingard for obtaining excellent cores and geochronology, to Emily Klein for use of the Duke University DCP, and to Takahiro Kamiya for advice on ostracode ecology. Bob Halley and Jeffery Stone provided FB temperature and salinity data. Dewitt Smith, Cecelia Weaver, and Angela Chong provided temperature and salinity data from Everglades National Park water monitoring stations. We thank Peter Swart for the use of his coral isotopic record and Dan Cayan for his CNP index. Dave Rudnick provided valuable insight into FB ecology and oceanography. D. Rudnick, D. A. Willard, D. Korejwo, A. J. Vega, and 2 anonymous reviewers provided valuable comments on the manuscript.

\section{LITERATURE CITED}

Barnett TP, Pierce DW, Saravanan R, Schneider N, Dommenget D, Latif M (1999) Origins of the midlatitude Pacific decadal variability. Geophys Res Lett 26:1453-1456

Brewster-Wingard GL, Ishman SE (1999) Historical trends in salinity and substrate in central Florida Bay: a paleoecological reconstruction using modern analogue data. Estuaries 22:369-383

Brewster-Wingard GL, Ishman SE, Holmes CW (1998) Environmental impacts on the southern Florida coastal waters: a history of change in Florida Bay. J Coast Res 26:162-172

Burton EA, Walter LM (1991) The effects of $\mathrm{PCO}_{2}$ and temperature on magnesium incorporation in calcite in seawater and $\mathrm{MgCl}_{2}-\mathrm{CaCl}_{2}$ solutions. Geochim Cosmochim Acta 55:777-785 
Cadot HM, Kaesler RL (1977) Magnesium content of calcite in carapaces of benthic marine Ostracoda. University of Kansas Paleontological Contributions, Paper 87, p 1-23

Cayan DR, Peterson DH (1989) The influence of north Pacific atmospheric circulation on streamflow in the West. Geophys Monogr 55:375-397

Chave KE (1954) Apsects of the biogeochemistry of magnesium 1. calcareous marine organisms. J Geol 62: 266-283

Chivas AR, DeDeckker P, Shelley JMG (1983) Magnesium, strontium, and barium partitioning in nonmarine ostracode shells and their use in paleoenvironmental reconstructions-a preliminary study. In: Maddocks RF (ed) Applications of Ostracoda. University of Houston Geoscience, p 238-249

Coleman JM (1988). Climatic warming and increased summer aridity in Florida, U.S.A. Clim Change 12:165-178

Cronin TM, Raymo ME (1997) Orbital forcing of deep-sea benthic species diversity. Nature 385:624-627

Cronin T, Willard D, Karlsen A, Ishman S and 6 others (2000) Climate variability in the eastern United States over the past millennium from Chesapeake Bay sediments. Geology $28: 3-6$

Cronin TM, Holmes C, Wingard L, Ishman SE, Dowsett H, Keyser D, Waibel N (2001) Historical trends in epiphytal ostracodes from Florida Bay: implications for seagrass and macro-benthic algal variability. In: Wardlaw B (ed) Ecosystem history of south Florida. Bull Am Paleontol 361: 163-204

De Deckker P, Chivas AR, Shelley JMG (1999) Uptake of Mg and $\mathrm{Sr}$ in the euryhaline ostracod Cyprideis determined from in vitro experiments. Palaeogeogr Palaeoclimatol Palaeoecol 148:105-116

Douglas AV, Engelhart PJ (1981) On a statistical relationship between Autumn rainfall in the central equatorial Pacific and subsequent winter precipitation in Florida. Mon Weather Rev 105:2377-2382

Duever MJ, Meeder JF, Meeder LC, McCollom JM (1994) The climate of south Florida and its role shaping the Everglades ecosystem. In: Davis SM, Ogden JC (eds) Everglades: the ecosystem and its restoration. St Lucie Press, Delray Beach, FL, p 225-248

Dunbar RB, Wellington GM, Colgan MW, Glynn PW (1994) Eastern Pacific sea surface temperature since 1600 A.D.: The $\delta^{18} \mathrm{O}$ record of climate variability in Galápagos corals. Paleoceanography 9:291-315

Dwyer GS, Cronin TM (2001) Ostracode shell chemistry as a paleosalinity proxy in Florida Bay. In: Wardlaw B (ed) Ecosystem history of south Florida. Bull Am Paleontol 361: 256-283

Dwyer GS, Cronin TM, Baker PA, Raymo ME, Buzas JS, Corrège $T$ (1995) North Atlantic deepwater temperature change during late Pliocene and late Quaternary climatic cycles. Science 270:1347-1351

Garbett EC, Maddocks RF (1978) Zoogeography of Holocene cytheracean ostracodes in the bays of Texas. J Paleontol 53:841-919

Halley RB, Roulier LM (1998) Reconstructing the history of eastern and central Florida Bay using mollusk-shell isotope records. Estuaries 22:358-368

Hanson K, Maul GA (1991) Florida precipitation and the Pacific El Niño, 1895-1989. Fl Sci 54:160-168

Henderson KG, Vega AJ (1996) Regional precipitation variability in the southern United States. Phys Geogr 17: 93-112

Holmes CW, Robbins JA, Halley RB, Bothner M, Ten Brink M, Marot M (1998) Sedimentary dynamics of Florida Bay mudbanks in a decadal time scale. Bull Am Paleontol 361:31-42

Holmes JA (1996) Trace-element and stable-isotope geochemistry of non-marine ostracod shells in Quaternary paleoenvironmental reconstruction. J Paleolimnol 15: 223-235

Jenkins GM, Watts DG (1968) Spectral analysis and its applications. Holden-Day, San Fransisco

Keyser D (1977) Brackwasser-Cytheracea aus Sud-Florida. Abh Verh Naturwiss Ver Hamburg NF 20:43-85

King CE, Kornicker LS (1970) Ostracoda in Texas bays and lagoons: an ecologic study. Smithson Contrib Zool 24:1-87

Latif M (1998) Dynamics of interdecadal variability in coupled ocean-atmosphere models. J Clim 11:602-624

Latif M, Barnett TP (1994) Causes of decadal climate variability over the North Pacific and North America. Science 266: 634-637

Latif M, Barnett TP (1996) Decadal climate variability over the North Pacific and North America: dynamics and predictability. J Clim 9:2407-2423

Leathers DJ, Palecki MA (1992) The Pacific/North American teleconnection pattern and United States climate. Part II: Temporal characteristics and index specification. J Clim 5: 707-716

Leathers DJ, Yarnal B, Palecki MA (1991) The Pacific/North American teleconnection pattern and United States climate. Part I: Regional temperature and precipitation associations. J Clim 4:517-528

McIvor CC, Ley JA, Bjork RD (1994) Changes in freshwater inflow from the Everglades to Florida Bay including effects on biota and biotic processes: a review. In: Davis SM, Ogden JC (eds) Everglades: the ecosystem and its restoration. St Lucie Press, Delray Beach, FL, p 117-146

Meehl GA, Arblaster JM, Strand WG Jr (1998) Global scale decadal climate variability. Geophys Res Lett 25: 3983-3986

Montroy DL (1997) Linear relation of central and eastern North American precipitation to tropical Pacific sea surface temperature anomalies. J Clim 10:541-558

Robbins JA, Holmes CW, Halley RB, Bothner M, Shinn E, Graney J, Keeler G, ten Brink M, Orlandini KA, Rudnick D (2000) Time-averaged fluxes of lead and fallout radionuclides to sediments in Florida Bay. J Geophys Res 105: 28805-28821

Robblee MB, Tilmant JT, Emerson J (1989) Quantitative observations on salinity. Bull Mar Sci 44:523

Rogers JC (1984) The association between the North Atlantic Oscillation and the Southern Oscillation in the Northern Hemisphere. Mon Weather Rev 112:1999-2015

Rogers JC, van Loon H (1979) The seesaw in winter temperatures between Greenland and Northern Europe. Part II: Some oceanic and atmospheric effects in the middle and high latitudes. Mon Weather Rev 107:509-519

Ropelewski CF, Halpert MS (1986) North American precipitation and temperature patterns associated with the El Niño/Southern Oscillation (ENSO). Mon Weather Rev 114: 2352-2362

Ropelewski CF, Halpert MS (1987) Global and regional scale precipitation patterns associated with the El Niño/Southern Oscillation. Mon Weather Rev 115:1606-1626

Sittel MC (1994a) Marginal probabilities of the extremes of ENSO events for temperature and precipitation in the southwestern United States. Center for Ocean-Atmosphere Prediction Studies Tech Rep 94-1

Sittel MC (1994b) Differences in the means of ENSO extremes for maximum temperature and precipitation in the United States. Center for Ocean-Atmosphere Predic- 
tion Studies Tech Rep 94-2

Slowey NC, Crowley TJ (1995) Interdecadal variability of northern hemisphere circulation recorded by Gulf of Mexico corals. Geophys Res Lett 22:2345-2348

Smith TJ, Hudson JH, Robblee MB, Powell GVN, Isdale PJ (1989) Freshwater flow from the Everglades to Florida Bay: a historical reconstruction based on fluorescent banding in the coral Solenastrea bournoni. Bull Mar Sci 44: $274-282$

Stahle DW, Cleaveland MK (1992) Reconstruction and analysis of spring rainfall over the southeastern U.S. for the past 1000 years. Bull Am Meteorol Soc 73:1947-1961

Stahle DW, Cleaveland MK, Blanton DB, Therrell MD, Gay DA (1998) The lost colony and Jamestown droughts. Science 280:564-567

Swart PK, Kramer PA (1997) Geology of mud islands in Florida Bay. In: Vacher HL, Quinn T (eds) Geology and hydrogeology of carbonate islands: developments in sedimentology 54:249-274

Swart PK, Healy GH, Dodge RE, Kramer P, Hudson JH, Halley RB, Robblee MB (1996) The stable oxygen and carbon isotopic record from a coral growing in Florida Bay: a 160 year record of climatic and anthropogenic influence. Paleogeogr Paleoclimatol Paleoecol 123:219-237

Swart PK, Healy G, Greer L, Lutz M, Saied A, Anderegg D, Dodge RE, Rudnick D (1999) The use of proxy chemical records in coral skeletons to ascertain past environmental conditions in Florida Bay. Estuaries 22:384-397

Thomas TM (1974) A detailed analysis of climatological and hydrological records of south Florida with reference to man's influence upon ecosystem evolution. In: Gleason PJ (ed) Environments of south Florida, past and present. Miami Geological Society Memoir 2, p 82-122

Thompson LG, Mosley-Thompson E, Morales Arnao B (1984) El Niño-Southern Oscillation events recorded in the

Editorial responsibility: Brent Yarnal,

University Park, Pennsylvania, USA stratigraphy of the tropical Quelccaya ice cap, Peru. Science 226:50-53

Tressler WL, Smith EM (1948) An ecological study of seasonal distribution of ostracoda, Solomons Island, Maryland, region. No. 71 Chesapeake Biological Laboratory, Solomons Island

Vega AJ, Sui CH, Lau KM (1998a) Interannual to interdecadal variations of the regionalized surface climate of the United States and relationship to generalized flow patterns. Phys Geogr 19:271-291

Vega AJ, Rohli RV, Henderson KG (1998b) The Gulf of Mexico mid-tropospheric response to El Niño and La Niña forcing. Clim Res 10:115-125

von Grafenstein U, Erlenkeuser H, Brauer A, Jouzel J, Johnsen SJ (1999) A mid-European decadal isotope-climate record from 15,500 to 5,000 years B.P. Science 284: $1654-1657$

Wallace JM, Gutzler DS (1981) Teleconnections in the geopotential height field during the Northern Hemisphere winter. Mon Weather Rev 109:784-811

Wanless HR, Tagett MG (1989) Origin, growth and evolution of carbonate mudbanks in Florida Bay. Bull Mar Sci 44: $454-489$

Wanless HR, Cottrell DJ, Tagett MG, Tedesco LP, Warzeski ER Jr (1995) Origin and growth of carbonate mudbanks in south Florida. In: Monty CV, Boscence DWL, Bridges $\mathrm{PH}_{\text {, }}$ Pratt BR (eds) Carbonate mud-mounds. Spec Publ Int Assoc Sedimentol 23:439-473

Wansard G (1996) Quantification of paleotemperature changes during isotopic stage 2 in the La Draga continental sequence (NE Spain) based on the $\mathrm{Mg} / \mathrm{Ca}$ ratio of freshwater ostracods. Quat Sci Rev 15:237-245

Yarnal B, Diaz HF (1986) Relationships between extremes of the Southern Oscillation and the winter climate of the Anglo-American Pacific coast. J Clim 6:197-219

Submitted: October 2, 2000; Accepted: May 25, 2001 Proofs received from author(s): Septemer 27, 2001 